\title{
Review
}

\section{A review on potential herbal treatments for 'dandruff' - the embarrassing scalp disorder}

Keragala RK ${ }^{1}$, Kempitiya $\mathrm{KS}^{1}$, Kumara $\mathrm{K}^{1}$, Kumarapeli NN ${ }^{1}$, Kasunsiri $\mathrm{TD}^{1}$, Gunathilaka $\mathrm{SS}^{1}$

${ }^{1}$ Faculty of Medicine and Allied Sciences, Rajarata University of Sri Lanka

\begin{abstract}
Dandruff is a scalp disorder that is characterized by itching, and abnormal and rapid turnover of the outermost layer of the skin of the scalp. The fungi of the genus Malassezia are responsible for causing dandruff. Several herbal remedies have been in use since ancient times for curing dandruff. The effectiveness of herbal extracts and their formulations against the fungi causing dandruff has been assessed previously. This review summarizes the findings of the studies which were focused on assessing the anti-dandruff effect of medicinal plants that are commonly available in Sri Lanka. Punica granatum, Mentha piperita, Bacopa monnieri, Asparagus racemosus, Azadirachta indica, Elaeocarpus serratus, Psidium guajava, Trigonella foenum-graecum, Cuminum cyminum, and Hibiscus spp. have been shown to be having in-vitro anti-malassezial action. However, the number of clinical trials done on assessing such effects of herbal preparations are limited, and the knowledge generated through the clinical trials hitherto shows that the use of combined preparations of plant extracts are successful in treating dandruff compared to single herb preparations.
\end{abstract}

Keywords: Dandruff, Malassezia spp., Herbal treatments, Home remedies, Antifungals

Copyright: ( 2020 Keragala RK et al. (c) (i) This is an open-access article distributed under the Creative Commons Attribution License, which permits unrestricted use, distribution, and reproduction in any medium, provided the original work is properly cited.

Funding: None

Competing interest: None

Correspondence: reshani.kaumada94@gmail.com

Cite this article as: Keragala et. al. A review on potential herbal treatments for 'dandruff' - the embarrassing scalp disorder. Anuradhapura Medical Journal 2020; 14 (1): 21-26.

DOI: http://doi.org/10.4038/amj.v14i1.7653 


\section{Introduction}

Dandruff is a scalp disorder characterized by itching and abnormal and rapid turnover of the outermost layer of the human scalp. The dead skin is usually released as patches and flakes of greyish-white colour (1). Dandruff and Seborrheic Dermatitis (SD) are the continuations of the same condition that affect skin areas with high sebum secretion. Dandruff is restricted to the scalp and involves itchy, flaking skin without visible inflammation. SD affects the scalp and other seborrheic areas and involves itchy and flaking or scaling skin, inflammation, and pruritus (2).

Three main factors encourage the formation of dandruff. They are fungal infections of the scalp, sebaceous secretions, and individual sensitivity to various chemical substances (3). The most widely accepted microbial organism is the lipophilic yeast which belongs to the genus Malassezia. $M$. restricta and $M$. globosa are the commonest species causing dandruff $(4,5)$.

Clinical symptoms associated with dandruff are skin flaking, pruritus, irritation, and the feeling of a dry or tight scalp. Loosely adherent, small white or grey flakes are characteristic of dandruff, whereas seborrheic dermatitis presents with yellowish oily scales (6). Though dandruff is not an easily contagious disease or a disease with serious clinical outcomes, it is an embarrassing condition that may affect self-confidence and even lead to psychological disturbances in more severe stages (2).

\section{Usual anti-dandruff treatments}

Active ingredients used in anti-dandruff medications include keratinolytic agents and antimicrobial agents. Salicylic acid, sulfur, and tar are the main keratinolytic agents used in dandruff treatment, while selenium sulfide, imidazole, flavonoids, phenolic acids, saponins, and hydroxypyridones are the key chemical constituents effective in treating dandruff (7). Table 01 shows the commonly used therapies for dandruff, which have been proven to be effective by in-vitro and/or clinical studies. Apart from those scientifically accepted medications, hundreds of commercial products in the form of shampoo, cream, scalp lotions are being sold and advertised worldwide. Some of them are claimed to contain 'anti-dandruff herbs', despite non-availability of research evidence (8). Furthermore, there are many herbal treatments in the form of home remedies used by people over many years.

Some of the herbal preparations have been tested, and significant anti-dandruff effects were reported in the literature. Evaluation of the in-vitro anti-malassezial effect is based on the demonstration of the zone of inhibition around a disk soaked with the aqueous or alcoholic extract of the herbal plant material under evaluation (9). In this review, we have summarized the publications that have described the anti-dandruff and/or anti-malassezial effects of various herbal preparations, which are commonly available in Sri Lanka.
Table 1: Commonly used anti-dandruff preparations with proven effectiveness

\begin{tabular}{|l|l|l|l|}
\hline \multicolumn{1}{|c|}{ Substance } & \multicolumn{1}{|c|}{ Preparation } & \multicolumn{1}{c|}{ Mechanism } & \multicolumn{1}{c|}{ Evidence } \\
\hline \multirow{2}{*}{ Ketoconazole } & $1-2 \%$ ketoconazole & $\begin{array}{l}\text { Decreasing both skin flakes } \\
\text { and Malassezial density }\end{array}$ & $\begin{array}{l}\text { Piérard-Franchimont C } \text { et } \\
\text { al, 2001(7) }\end{array}$ \\
\cline { 2 - 5 } & $\begin{array}{l}\text { Ketoconazole coated } \\
\text { silver nanoparticles } \\
\text { (AgNp) }\end{array}$ & $\begin{array}{l}\text { AgNp enhance the activity of } \\
\text { ketoconazole penetrating } \\
\text { through the cell membrane } \\
\text { leading to the destruction of } \\
\text { the fungus }\end{array}$ & MathewJ et al, 2015(10) \\
\hline Selenium sulfide & $\begin{array}{l}2.5 \% \text { selenium sulfide } \\
\text { shampoo }\end{array}$ & $\begin{array}{l}\text { An anti-hyperkeratotic agent } \\
\text { that can be used effectively } \\
\text { for the treatment of seborrheic } \\
\text { dermatitis which is a severe } \\
\text { form of dandruff. }\end{array}$ & $\begin{array}{l}\text { Sheth RA. 1983 (11) } \\
\text { Rosenthal D, Margesson LJ } \\
, 1993(12)\end{array}$ \\
\hline Ciclopirox & $1 \%$ shampoo & $\begin{array}{l}\text { Exhibits antifungal activity } \\
\text { against Malassezia spp }\end{array}$ & $\begin{array}{l}\text { Lebwohl M, Plott T 2004 } \\
\text { (13) }\end{array}$ \\
\hline $\begin{array}{l}\text { Topical } \\
\text { Corticosteroid } \\
\text { Therapy (TCS) }\end{array}$ & $\begin{array}{l}\text { Low to low-mid potency } \\
\text { TCS }\end{array}$ & $\begin{array}{l}\text { Anti-pruritic and anti- } \\
\text { inflammatory effect }\end{array}$ & Del Rosso JQ, 2011(14) \\
\hline
\end{tabular}

Medicinal plant preparations tested for antifungal effects

Punica granatum (English: Pomegranate, Sinhala: Delum, Tamil: Madalai)

Punica granatum belongs to the family Punicaceae. The studies done by Gill et al. (15) and Alireza et al. (16) have demonstrated that the chemical constituents in Punica inhibits pro-inflammatory cytokines. Furthermore, it has been shown that Punica granatum has anti-inflammatory, anti-itching, anti-dandruff and anti-oxidant properties $(17,18)$. In a clinical trial done in 2014 in Iran (19), a herbal shampoo prepared with methanol extract of flowers of Punica granatum in combination with other six medicinal plants, Rosmarinus officinalis, Matricaria chamomilla, Urtica dioica, Mentha piperita, Salvia officinalis, and Pirocton olamine had shown effectiveness on dandruff removal, with fewer side effects (19).

Mentha piperita (English: Peppermint, Sinhala: Minchi, Tamil: Pudina)

Mentha piperita is a plant of the family Labiate, which is widespread across the world while mainly found in Europe. Some flavonoids in Mentha piperita leaves, such as menthoside rosmarinic acid and tannins, can inhibit bacterial, fungal, and yeast growth (20). An Iranian research group has observed significant antimalassezial effects of essential oils made up of Mentha piperita (19).

Bacopa monnieri (English: Waterhyssop, Sinhala: Lunuwila, Tamil: Nīrppirami)

Phytochemical analysis of Bacopa monnieri leaves has revealed the presence of tannin, saponin, steroids, flavonoids, phenol, and alkaloids, which are known chemicals to have anti-dandruff effects (21). Crude aqueous and ethanoic extracts of $B$. monniera have been tested for the antifungal effects against the dermatophytic fungi. In the results of that study, both ethanoic extract and aqueous extracts had high inhibitory action against the studied dermatophytic fungus (22). 
Though the effect of Bacopa against Malassezia spp. is not available in published literature, it may be reasonable to expect some effect against dandruff as the isolated chemical constituents include steroids which have antipruritic action and in use as a treatment in dandruff (Table 02).

Asparagus racemosus (English: Asparagus, Sinhala: Hathawariya, Tamil: Shatavari)

Asparagus racemosus root extract has shown in-vitro antifungal effects against dandruff causing yeasts $M$. globosa and M. furfur (23). Together with its inherent anti-inflammatory effect $A$. racemosus, is considered a potential ingredient in anti-dandruff formulations (24).

Azadirachta indica (English: Neem, Sinhala: Kohomba, Tamil: Veppai)

Saranya et al. (25) have revealed that the silver nanoparticles synthesized through green synthesis using Azadirachta indica leaf extract inhibit the growth of Malassezia spp. in-vitro. Neem extract has been reported to be having an anti-pityrosporum activity (26).

Elaeocarpus serratus (English: Ceylon olive, Sinhala: Veralu Tamil: Karamaram) and

Psidium guajava (English: Guava, Sinhala: Pera, Tamil: Caițiyam koyyā)

In ayurvedic medicine, a paste made of the leaves of Elaeocarpus serratus and Psidium guajava were used for many years in Sri Lanka. The anti-dandruff action of E. serratus and $P$. guajava paste was assessed clinically in Sri Lankan patients by Pramodini and Wickramarachchi (27) and concluded that the paste is effective managing dandruff.

Trigonella foenum-graecum (English: Fenugreek, Sinhala: Uluhal, Tamil: Vendayam)

The leaf extracts of Trigonella foenum - graecum have been found to have an antifungal effect in a study in India (28). Aqueous preparation of germinated fenugreek seeds has been able to produce a zone of inhibition in Malassezia growth, suggesting the possibility of using it as an anti-dandruff agent.

\section{Cuminum cyminum (English: Cumin; Sinhala: Sooduru, Tamil: Cīrakam)}

Essential oil prepared with Cuminum cyminum seeds has shown inhibition zones larger in size than the antifungal medication ketoconazole when tested against Malassezia spp. (19). Furthermore, cumin is known to consist of anti-allergic and anti-inflammatory properties, which may contribute to the beneficial effects as a potential herbal treatment against dandruff (29).

Hibiscus spp. (English: Hibiscus/Roselle; Sinhala: Vada, Tamil: Cemparutti)

The butanolic extract of Hibiscus sabdarifa has been tested by Surabhi Pisal and Vaishali Mane (30) using the well diffusion method. They have reported that the zone of inhibition is $25 \mathrm{~mm}$ with a $100 \%$ concentration of the extract. Extracts of flowers of Hibiscus rosa - sinensis has also shown in-vitro anti - Malassezial effects.

\section{Discussion}

This review summarizes the findings of the studies which were focused on assessing the anti-dandruff effect of medicinal plants that are commonly available in Sri Lanka. Most of the above studies were in-vitro tests of plant aqueous or ethanoic extracts. Only a few clinical studies were available in the literature with promising results, of which some were done using preparations made by combining several plant materials. Interpretations, comparisons, and reproducibility of results may be difficult in such studies done using combined preparations.

The studies which have assessed the zones of inhibition for the Malassezia spp. grown on agar-based media may be comparable. However, a comparison of the sizes of the zone of inhibition between studies may not be precise as the media used and the anti-fungal sensitivity test methods involved were different across the studies. Therefore, observation of a significant inhibition zone as defined by the authors of each study was considered as the presence of the anti-dandruff effect for this review. The reviewers would like to suggest further in-vitro as well as clinical studies on these identified herbs, Punica granatum (pomegranate), Cuminum cyminum (cumin), Trigonella foenum-graecum (fenugreek), Hibiscus spp. (vada), Bacopa monnieri (water hyssop), Azadirachta indica (kohomba, neem), and Mentha piperita (peppermint) to investigate the safety profile and to purify the chemical constituents with anti-dandruff property, etc. Pramodini and Wickramarachchi (27), in their clinical study done in Sri Lanka testing the efficacy of a paste made with leaves of Elaeocarpus serratus (veralu) and Psidium guajava (pera), which are in traditional medicine as a home remedy for dandruff in Sri Lanka, has reported promising results with remarkable symptomatic improvement and complete control of dandruff, with minimum adverse effects (34). Since the authors have not described the preparation of the tested product in detail, the reproducibility of such a result is somewhat questionable. However, we believe further evaluations of such preparation for product development will be worthwhile.

In conclusion, the aqueous and ethanoic extracts of herbs that have demonstrated anti-Malassezia effects in invitro tests include several commonly available plants in Sri Lanka. As some of these are traditional home remedies are already in use for years, the development of commercial products after establishing proper scientific clinical evidence should be encouraged. 
Table 2: Herbs with anti-dandruff properties

\begin{tabular}{|c|c|c|c|c|c|}
\hline Plant & Preparation & $\begin{array}{l}\text { Possible effect } \\
\text { on dandruff }\end{array}$ & $\begin{array}{c}\text { Chemical } \\
\text { substances with } \\
\text { anti-dandruff } \\
\text { activity }\end{array}$ & Evidence & Remarks \\
\hline Punica granatum & $\begin{array}{l}\text { Herbal } \\
\text { shampoo } \\
\text { prepared with } \\
\text { methanol } \\
\text { extract of } \\
\text { flowers }\end{array}$ & $\begin{array}{l}\text { Anti- } \\
\text { malassezial } \\
\text { effect } \\
\text { Anti- } \\
\text { inflammatory } \\
\text { and anti- } \\
\text { pruritic effect }\end{array}$ & $\begin{array}{l}\text { Saponin, } \\
\text { Steroids } \\
\text { Phenol }\end{array}$ & $\begin{array}{l}\text { Gil MI et al.,2000(15) } \\
\text { Ghasemian A et al., } \\
\text { 2006(16) } \\
\text { Naeini AR et al., } 2019 \\
(19)\end{array}$ & $\begin{array}{l}\text { Punica granatum, in } \\
\text { combination with six other } \\
\text { medicinal plants, } \text { Rosmarinus } \\
\text { officinalis, Matricaria } \\
\text { chamomilla, Urtica dioica, } \\
\text { Mentha piperita, and Salvia } \\
\text { officinalis, and Pirocton } \\
\text { olamine, has shown } \\
\text { effectiveness on dandruff } \\
\text { removal with fewer side } \\
\text { effects in a clinical study (31). }\end{array}$ \\
\hline Mentha piperita & $\begin{array}{l}\text { Essential oils } \\
\text { prepared from } \\
\text { leaves }\end{array}$ & $\begin{array}{l}\text { Inhibition of } \\
\text { fungal growth }\end{array}$ & $\begin{array}{l}\text { Flavonoids } \\
\text { Rosmarinic } \\
\text { acid } \\
\text { Tannins }\end{array}$ & $\begin{array}{l}\text { Naeini AR et al., } 2019 \\
(19) \\
\text { Paul Rita and Animesh } \\
\text { DK 2011(20) }\end{array}$ & $\begin{array}{l}\text { Commercial preparations } \\
\text { consisting of essential oils } \\
\text { (EO) of Mentha piperita, } \\
\text { Citrus } \\
\text { aurantium, Lavandula, origan } \\
\text { um vulgare, Origanum } \\
\text { majorana, and Helichrysum } \\
\text { italicum was reported }\end{array}$ \\
\hline Bacopa monnieri & $\begin{array}{l}\text { Crude } \\
\text { aqueous and } \\
\text { ethanoic } \\
\text { extracts of } \\
\text { leaves }\end{array}$ & $\begin{array}{l}\text { Inhibition of } \\
\text { fungal growth }\end{array}$ & $\begin{array}{l}\text { Tannin } \\
\text { Phlobatannin, } \\
\text { Saponin, } \\
\text { Steroids, } \\
\text { Flavonoid, } \\
\text { Cardiac } \\
\text { Glycosides, } \\
\text { Phenol, } \\
\text { Alkaloids }\end{array}$ & $\begin{array}{l}\text { Jain P et al., 2017(21) } \\
\text { Ayyappan SR et } \\
\text { al.,,2013 (22) }\end{array}$ & No clinical studies available \\
\hline Asparagus racemosus & Root extracts & $\begin{array}{l}\text { In-vitro } \\
\text { antifungal } \\
\text { effects } \\
\text { against } \\
\text { dandruff } \\
\text { causing } \\
\text { yeasts } M \text {. } \\
\text { globosa and } \\
M \text {. furfur(32) }\end{array}$ & Not established & $\begin{array}{l}\text { Onlome C et } \\
\text { al.,2019(23) } \\
\text { Battu GR, Kumar BM } \\
2010(24)\end{array}$ & No clinical studies available \\
\hline Azadirachta indica & Leaf extracts & $\begin{array}{l}\text { Anti- } \\
\text { pityrosporum } \\
\text { activity }\end{array}$ & $\begin{array}{l}\text { Phenols } \\
\text { Flavonoids } \\
\text { Nimbin }\end{array}$ & $\begin{array}{l}\text { Saranya et al.,2014(25) } \\
\text { Prabhamanju et al., } \\
\text { 2009(26) }\end{array}$ & $\begin{array}{l}\text { A poly-herbal hair oil } \\
\text { containing Azadirachta } \\
\text { indica extracts and other five } \\
\text { constituents was found to } \\
\text { have activity against } P \text {. ovale } \\
\text { in-vitro by Krishnamoorthy et } \\
\text { al. } 2006(33)\end{array}$ \\
\hline Elaeocarpus serratus & Leaves paste & $\begin{array}{l}\text { Antifungal } \\
\text { and anti- } \\
\text { inflammatory } \\
\text { effects }\end{array}$ & $\begin{array}{l}\text { Phenols } \\
\text { Flavonoid } \\
\text { Tannins }\end{array}$ & $\begin{array}{l}\text { Pramodani et al., } \\
(2019)(34)\end{array}$ & $\begin{array}{l}\text { An excellent anti-dandruff } \\
\text { action of Elaeocarpus } \\
\text { serratus leaves paste is } \\
\text { reported in a clinical study by } \\
\text { Pramodani et al. }(2019)(34)\end{array}$ \\
\hline
\end{tabular}




\begin{tabular}{|c|c|c|c|c|c|}
\hline Psidium guajava & Leaves paste & $\begin{array}{l}\text { Antifungal and } \\
\text { anti- } \\
\text { inflammatory } \\
\text { effects }\end{array}$ & $\begin{array}{l}\text { Tannins } \\
\text { Polyphenolic } \\
\text { compounds } \\
\text { Flavonoids }\end{array}$ & $\begin{array}{l}\text { Pramodani } \text { et al., } \\
(2019)(34)\end{array}$ & $\begin{array}{l}\text { The excellent anti-dandruff } \\
\text { action of Psidium guajava } \\
\text { leaves paste is reported in a } \\
\text { clinical study by Pramodani et } \\
\text { al. (2019). (34) }\end{array}$ \\
\hline $\begin{array}{l}\text { Trigonella foenum- } \\
\text { graecum }\end{array}$ & $\begin{array}{l}\text { Aqueous } \\
\text { preparation }\end{array}$ & $\begin{array}{l}\text { Antifungal } \\
\text { effect }\end{array}$ & $\begin{array}{l}\text { Saponins } \\
\text { Alkaloids }\end{array}$ & $\begin{array}{l}\text { Dharajiya et al., } 2019 \\
(28)\end{array}$ & No clinical studies available \\
\hline Cuminum cyminum & Essential oil & $\begin{array}{l}\text { In-vitro anti- } \\
\text { malassezial } \\
\text { effect }\end{array}$ & $\begin{array}{l}\text { Flavonoid } \\
\text { Phenols }\end{array}$ & $\begin{array}{l}\text { Naeini AR et al., } 2019 \\
\text { (19) } \\
\text { Sowbhagya HB } \\
2016(29)\end{array}$ & No clinical studies available \\
\hline Hibiscus spp. & $\begin{array}{l}\text { The butanolic } \\
\text { extract of } \\
\text { Hibiscus } \\
\text { sabdarifa }\end{array}$ & $\begin{array}{l}\text { In-vitro } \\
\text { antifungal } \\
\text { effect }\end{array}$ & $\begin{array}{l}\text { Flavonoid } \\
\text { Phenolic acids } \\
\text { Tannins }\end{array}$ & $\begin{array}{l}\text { Pisal S, Mane V } 2105 \\
\text { (30) }\end{array}$ & No clinical studies available \\
\hline
\end{tabular}

\section{References}

1. Shu'aibu I, Hauwa S, Fatima UM, Muhd MM. Isolation and identification of Malassezia globosa, associated with dandruff among female students of Gombe State University. Greener J Microbiol Antimicrob. 2013;1(1):001-6. DOI:10.15580/gjma.2013.1.080913827

2. Luis J. Borda TCW. Seborrheic dermatitis and dandruff: A comprehensive review. J Clin Investig Dermatology . 2015;3(2):10. DOI:10.13188/2373-1044.1000019

3. Deangelis YM, Gemmer CM, Kaczvinsky JR, Kenneally DC, Schwartz JR, Dawson TL. Three etiologic facets of dandruff and seborrheic dermatitis : Malassezia fungi, sebaceous lipids, and individual sensitivity. J Investig Dermatology Symp Proc 2005;10(3):295-7. DOI: 10.1111/j.1087-0024.2005.10119.x

4. Zisova LG. Malassezia species and seborrheic dermatitis. Folia Med (Plovdiv).2009;51(1):23-33.

5. Piérard-Franchimont C, Xhauflaire-Uhoda E, Piérard GE. Revisiting dandruff. Int J Cosmet Sci. 2006;28(5):311-8. DOI: $10.1111 / \mathrm{j} .1467-2494.2006 .00326 . x$

6. Grimalt R. A practical guide to scalp disorders. J Invest Dermatol 2007;12(2):10-14. DOI: 1038/sj.jidsymp.5650048

7. Piérard-Franchimont C, Piérard GE, Arrese JE, De Doncker P. Effect of ketoconazole 1\% and 2\% shampoos on severe dandruff and seborrhoeic dermatitis: Clinical, squamometric and mycological assessments. Dermatology; 2001;202(2):171-6. DOI: 10.1159/000051628

8. Ranganathan S, Mukhopadhyay T. Dandruff: The most commercially exploited skin disease. Indian J Dermatol. 2010;55(2):130-4. DOI:10.4103/0019-5154.62734

9. Saubolle MA, Hoeprich PD. Disk agar diffusion susceptibility testing of yeasts. Antimicrob Agents Chemother. 1978;14(4):517-30. DOI:10.1128/AAC.14.4.517

10. Mathew J, Rathod V, Singh D, Ninganagouda S, Singh K, Kulkarni P. Enhanced efficacy of ketoconazole coated silver nanoparticles against the fungus Malassezia furfur a dandruff causing agent. World J Pharm Pharm Sci. 2015;4(06):1246-58.

11. Sheth RA. A Comparison of miconazole nitrate and selenium disulfide as anti-dandruff agents. Int J Dermatol. 1983;22(2):123-5. DOI:10.1111/j.1365-4362.1983.tb03330.x

12. Rosenthal D, Margesson LJ. A randomized, double-blind, placebo-controlled trial of ketoconazole $2 \%$ shampoo versus selenium sulfide $2.5 \%$ shampoo in the treatment of moderate to severe dandruff. $\mathrm{J}$ Am Acad Dermatol. 1993;29(6):1008-12. DOI:10.1016/0190-9622(93)70282-X

13. Lebwohl M, Plott T. Safety and efficacy of ciclopirox $1 \%$ shampoo for the treatment of seborrheic dermatitis of the scalp in the US population: Results of a double-blind, vehicle-controlled trial. Int J Dermatol. 2004;43 Suppl 1:1720. DOI: $10.1111 /$ j.1461-1244.2004.02409.x 
14. Del Rosso JQ. Adult seborrheic dermatitis: A status report on practical topical management. J Clin Aesthet Dermatol.. 2011;4(5):32-8.

15. Gil MI, Tomas-Barberan FA, Hess-Pierce B, Holcroft DM, Kader AA. Antioxidant activity of pomegranate juice and its relationship with phenolic composition and processing. J Agric Food Chem. 2000;48(10):4581-9. DOI:10.1021/jf000404a

16. Ghasemian A, Mehrabian S, Ahmad Majd. Peel extracts of two Iranian cultivars of pomegranate (Punica granatum) have antioxidant and antimutagenic activities. Pakistan J Biol Sci. 2006;9(7):1402-5. DOI: 10.3923/pjbs.2006.1402.1405

17. Elfalleh W. Total phenolic contents and antioxidant activities of pomegranate peel, seed, leaf and flower. J Med Plants Res. 2012;6(32):4724-30. DOI:10.5897/JMPR11.995

18. De Souza Vasconcelos LC, Correia Sampaio MC, Correia Sampaio F, Higino JS. Use of Punica granatum as an antifungal agent against candidosis associated with denture stomatitis. Mycoses. 2003;46(5-6):192-6. DOI:10.1046/j.1439-0507.2003.00884.x

19. Naeini AR, Nazeri M, Shokri H. Inhibitory effect of plant essential oils on Malassezia strains from Iranian dermatitis patients. J HerbMed Pharmacol. 2018;7(1):18-21. DOI:10.15171/jhp.2018.04

20. Paul Rita and Animesh DK. An updated overview on peppermint (Mentha piperita). Int Res J Pharm. 2011;2(8):110.

21. Jain P, Sharma HP, Basri F, Priya K, Singh P. Phytochemical analysis of Bacopa monnieri (L.) Wettst. and their antifungal activities. Indian J Tradit Knowl. 2017;16(2):310-8.

22. Ayyappan SR, Srikumar R, Thangaraj R, Jegadeesh R, Hariprasath L. Antifungal activity of Bacopa monnieriagainst dermatophytic fungus. Biomedicine. 2011;31(1):74-7.

23. Onlom C, Khanthawong S, Waranuch N, Ingkaninan K. In-vitro anti- Malassezia activity and potential use in antidandruff formulation of Asparagus racemosus. Int J Cosmet Sci. 2014;36(1):74-8. DOI: 10.1111/ics.12098

24. Battu GR, Kumar BM. Anti-inflammatory activity of leaf extract of Asparagus racemosus Willd. Int J Chem Sci. 2010;8(2):1329-38.

25. Saranya S, Vijayarani K, Ramya K, Revathi K, Kumanan K. Synthesis and characterization of silver nanoparticles using Azadirachta indica leaf extract and their anti-fungal activity against Malassezia species. J Nano Res. 2016;43:1-10.DOI: 10.4028/www.scientific.net/JNanoR.43.1

26. Prabhamanju M, Shankar SG, Babu K. Herbal vs. chemical actives as antidandruff ingredients -Which are more effective in the management of dandruff?- An overview. Ethnobotanical Leaflets. 2009; 11:Article 5.

27. Pramodani MPN, Wickramarachchi WJ. A clinical study to evaluate the efficacy of selected traditional hair pack for dandruff. Int J Res. 2017;5(1):12-21. DOI: 10.5281/zenodo.259367.

28. Dharajiya D, Jasani H, Khatrani T, Kapuria M, Pachchigar K, Patel P. Evaluation of antibacterial and antifungal activity of fenugreek (Trigonella foenum-graecum) extracts. Int J Pharm Pharm Sci. 2016;8(4):212-7.

29. Sowbhagya HB. Chemistry, technology, and nutraceutical functions of cumin (Cuminum cyminum L): An overview. Crit Rev Food Sci Nutr. 2013;53(1):1-10. DOI:10.1080/10408398.2010.500223

30. Pisal S, Mane V. Studies on Antifungal activities of certain plant extracts against dandruff-causing fungus, Malassezia. Int J Curr Res Biosci Plant Biol. 2015;7:206-11.

31. Sahraie-Rad M, Izadyari A, Rakizadeh S, Sharifi-Rad J. Preparation of strong antidandruff shampoo using medicinal plant extracts: A clinical trial and chronic dandruff treatment. Jundishapur J Nat Pharm Prod. 2015;10(4):e21517. DOI:10.17795/jjnpp-21517

32. Onlom C, Khanthawong S, Waranuch N, Ingkaninan K. In-vitro anti- Malassezia activity and potential use in antidandruff formulation of Asparagus racemosus. Int J Cosmet Sci. 2014;36(1):74-8. DOI:10.1111/ics.12098

33. Krishnamoorthy JR, Ranganathan S, Shankar SG, Ranjith MS. Dano: A herbal solution for dandruff. African J Biotechnol.2006;5(10):960-2. DOI:10.5897/AJB05.285

34. Pramodani MPN, Wickramarachchi WJ. A clinical study to evaluate the efficacy of selected traditional hair pack for dandruff. Int J Res. 2017;5(1):12-21. DOI: 10.5281/zenodo.259367.

Submit your next manuscript to
Anuradhapura
Medical Journal
htt://ami.sljol.info/

